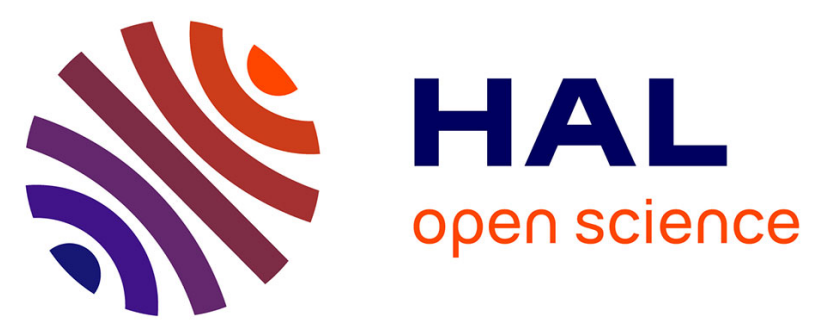

\title{
Images of women in literature on physical education and sport: Representations of social transformation in France under the Third Republic, 1870-1939
} Jacques Gleyse, Céline Garcia, Canal Jean-Luc, Susan E Matthews

\section{- To cite this version: \\ Jacques Gleyse, Céline Garcia, Canal Jean-Luc, Susan E Matthews. Images of women in lit- erature on physical education and sport: Representations of social transformation in France un- der the Third Republic, 1870-1939. Sport, Education and Society, 2004, 9 (3), pp.327-345. 10.1080/13573320412331302421 . hal-01334310}

\author{
HAL Id: hal-01334310 \\ https://hal.science/hal-01334310
}

Submitted on 21 Jun 2016

HAL is a multi-disciplinary open access archive for the deposit and dissemination of scientific research documents, whether they are published or not. The documents may come from teaching and research institutions in France or abroad, or from public or private research centers.
L'archive ouverte pluridisciplinaire HAL, est destinée au dépôt et à la diffusion de documents scientifiques de niveau recherche, publiés ou non, émanant des établissements d'enseignement et de recherche français ou étrangers, des laboratoires publics ou privés. 
Images of Women in the Literature on Physical Education and Sport. Representations of Social Transformation in France under the Third Republic, 1870-1939?

Jacques Gleyse*, Céline Garcia \& Jean-Luc Canal*

Team Body \& Culture, School of Sport and Physical Education Sciences, University of Montpellier,

* and I.U.F.M. (University Institute for Teacher's Formation) Montpellier

Translation : Susan Matthews, Montpellier. 


\begin{abstract}
Writings on "the female" under the Third Republic in France provide evidence of the profound changes taking place in the social representation of femininity and masculinity during the period. They correspond to dramatic changes in the socioeconomic context in parallel with those in the scientific models being used to describe human bodily movement. This paper sets out to demonstrate both the structure of the discussion on femininity and the practice of exercise, and the possible links with changes in women's education and their social position in France. It attempts to go beyond the traditional analysis of the historical relationships between women and exercise in the period under examination (1870-1939). It reviews the debates on these relationships taking place at the time in France and within the state education system during the Third Republic and focuses on three specific aspects: work, school and society.
\end{abstract}




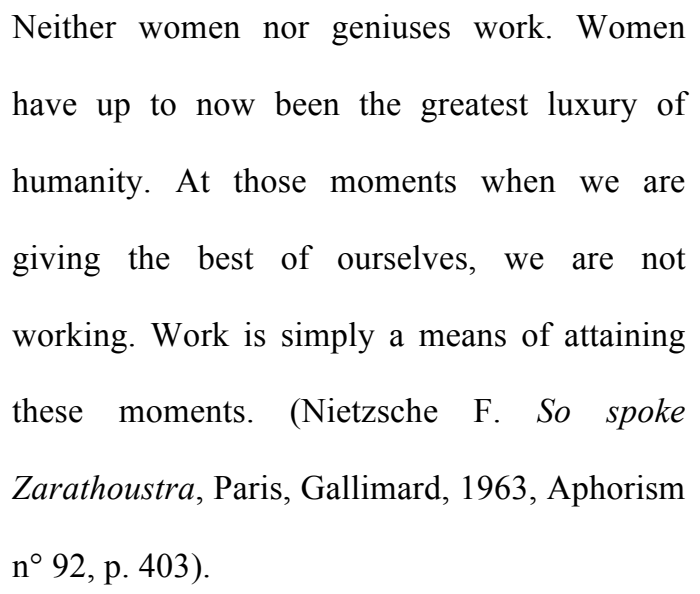

\section{Introduction}

Co-educational physical education in secondary and primary schools was introduced in France around 1960 (it was permitted in 1957 and became the norm only in the official curriculum in 1975). In terms of physical education and sports education (PE\&S) in France, the debate became extremely lively after the strikes and demonstrations that occurred in May 1968, and became more heated with the setting up in 1975 of a single sex collège (for 11-15 year-olds), which coincided with the passing of the Weil law on contraception and abortion rights. A major enquiry conducted by the Minister of National Education in 1983 revealed that teachers of Physical Education and Sport (PE\&S) were generally in favour of mixed classes. Older teachers were less likely to support the idea: $76 \%$ of those aged under 30 gave their support, while only $32 \%$ aged over $55 \mathrm{did}$ so. In the same study it was found that women were less in favour of mixed classes than were men ( $47 \%$ of women, $54 \%$ of men). However, among children at collège and lycée the enquiry showed that the older the child, the more s/he had a positive attitude to mixed classes (nearly $90 \%$ of those in Terminale - their final school year). Yet although the majority of the younger children $(51 \%)$ were in favour of this move, very young ones were less positive. The same enquiry showed too, that mixed classes were actually operating only in a minority of school establishments, although by 
now they had long been legal. Thus there continued to be a large gap between aspiration and implementation. The debate on mixed classes continues (Davisse, Louveau, 2000). Today, while the practice has become widespread ( $87 \%$ of PE\&S classes are mixed), a new debate is taking place on the need for the positive segregation of girls. This debate is associated firstly with the observation that examination marks obtained by girls for $\mathrm{PE} \& \mathrm{~S}$ in the baccalauréat are on average lower by almost one point than those obtained by boys (statistically significant and evidence of either the under-marking of girls or inappropriate tests (Hébrard 1986)); and secondly, with the idea that the education system in general should operates on the basis of a "gender-neutral" but in fact leans to a masculin-norm. Nicole Mosconi (2000) see the situation as being "masculin-neutre". In other words, the education program covertly discriminates against girls. A study of school manuals in France (Mosconi, 1987) seems to confirm that the school curriculum discriminates against girls.

Yet, despite persistent problems of sexism in France it cannot be denied that since 1882 when schooling became mandatory for them, girls and young women have successfully established a position both in PE\&S and in the overall educational system.

In this paper we review the discourse on work, society, school and PE\&S in order to clarify the historical (and archaeological) factors that have brought about this change. The analysis focuses on relationships between women's place in society and school and on physical practices under the Third Republic in France. It seeks through an analysis of the past, to throw light on present trends.

Several studies in the French language (Arnaud \& Terret, 1996; Davisse \& Louveau, 1991) have been clearing the ground regarding the historical relationship between women and sport and physical education in France. Our work also draws on English language research. Sheila Scraton's work (1992) for example is a particularly 
pertinent study into how the foundations and traditions in physical education led to current physical education practice and shows how it was influenced by them. Her work also highlights that physical education conveys strong gender messages, challenging myths concerning women's bodies, strength and physicality. In short, physical education reinforces the image of femininity and develops appropriate gender behaviour as well as providing a potential for change and non-sexist schooling. In a solely historical context Richard Holt has conducted research that is similar to the work that follows here. His paper, entitled "Women, men and sport in France, c. 1870-1914: an introductory survey" (1991) addressed this very topic in the history of sport during part of the period examined in the essay that follows. However, his article was based on a number of epistemological and methodological decisions that, although pertinent, are not the only ones possible. The same applies to his sources. As Holt says himself, his article constitutes an introduction. The paper that follows tries to go a little further by considering the particular issue of femininity in sport and physical education in relation to the situation of national schooling and employment under the Third French Republic. Yet there remains a relatively broad primary approach that might be better explained later. The originality of the paper perhaps is that it explores archives that are little known outside France (although some are now familiar to English-speaking readers) and also that it attempts to link three areas in the discourse: society, the world of work, and the school environment including physical education.

A multitude of English language authors, including those published in this journal, have also shown an interest in examining this subject whether in historical terms, or in sociological or pedagogic terms. In particular Emma Renold (1997), Gill Clarke (1998) Jan Wright (1995) and John Evans, Brian Davies \& Dawn Penney (1996) come to mind. But none of these papers, of considerable interest in their particular 
fields of study, deals with the historical roots of coeducation in France. These papers moreover, basically concentrate on the classroom lesson itself without looking at the social and historical background to the subject.

Anthony Fletcher's historical research (1999), while not setting out to explore physical education, does provide a fuller theoretical understanding of how the patriarchal system, inherited from the model described in the Bible, has been redefined by ideological modernity during the period under examination (1500-1800), in particular by separating it from its biblical base. His research provides a springboard for this study, which is concerned specifically with women's physical education in France during the Third Republic, to the extent that the female role has been redefined in a modern perspective. In the same sense, David Kirk's work, especially in Schooling Bodies (Kirk, 1998) provides a pertinent analysis of the social processes affecting P.E. in England and Australia. He explains in particular how: "The docile body produced by these practices was both pliable and yet economically productive, a body that could be regulated and normalized to economically-productive citizens." The paper that follows also seeks to establish that these processes were also evident in France. It sets out to examine how, under the Third Republic in France, female emancipation through physical education meant emancipation from the patriarchal model for culturally favoured social classes, and submission to a productive economic model at least during this period. Two books by Hargreaves (1994 and 2000) perfectly illustrate the relationships between class and gender. They also demonstrate the complex and paradoxical nature of feminine sport. The concepts examined by Hargreaves are similar to those that stimulated the study that follows, although his papers are more concerned with the problem of social class (from a Bourdieuan perspective), which is not the concern of the work offered here. This study seeks primarily to examine an épistémê (in 
Foucauld's terms, meaning the scientific spirit of the times) and a regulatory system in a particular discourse in a particular period. In these terms, this paper will not necessarily enable practical conclusions to be drawn, except when realising, again using Foucault's approach, that the discourse also produces institutions and organisations.

To reiterate, the work submitted here focuses on State physical education in France, particularly during the Third Republic and on the relationship between society and the education system demonstrated by the discourse held on this specific topic. In terms of epistemology, this article employs the archaeological methodology already pursued in other aspects of bodily practice (Gleyse, 1995 and 1997). While the term archaeology is commonly accepted as meaning to reconstitute a world using the remains discovered during a dig, L'Archéologie des discours (the archaeology of writings), which was initiated by Michel Foucault (1961, 1966, 1969, 1971, 1975), tries to give intelligibility to the discursive remains in a particular intellectual field. It thus constitutes "chains of inference" (Foucault, 1969, p. 53), "tables of inference" (Foucault, 1969, p. 53) or even better, it describes "systems of dispersion" (Foucault, 1969 , p. 53.) providing for the genesis, growth, affiliation and sometimes for the demise too of a discursive system. Consequently, it attempts to identify the "training rules" (Foucault, 1969, p. 53.) for the discursive statement. In this paper a selection of both disseminated and unpublished statements issued on the subject of women's sport and physical education will be presented as a "formation discursive" (Foucault, 1969, p. 53), in other words, as a closed yet permeable collection of writings and related corporeal practices. Thus it is more concerned to highlight a "discourse order", drawing its theory from the first of Foucault's papers, than to be a study of the constraint and monitoring systems that are presented for example in Surveiller et punir (Foucault, 1975). 
This serves as a comparison of the organisations and situations that impelled the transformation of employment and scholastic education (Gleyse, 1995 and 1997). If, paraphrasing Michel Bernard (1976, p. 134), it is admitted that "the writings on physical education are symbolic of the expressions used by society when talking of the body as an instrument of fantasy rationalisation" (Gleyse, p. 9), the writings on women in this arena are evidently an expression of the synchronic and diachronic mutations and ruptures of the socius. The changes occurring in the position of the female in physical education cannot be understood without considering the changes in her position in school and society. Essentially, all three are linked. Thus, to try to comprehend, as have Annick Davisse and Catherine Louveau (1991), the three-way interaction between school, society and sport since the end of the nineteenth century, without making reference to the overall quantitative and qualitative modifications that have taken place in the scholastic education of girls (Lelièvre, 1991) and more generally, to the drastic changes in the organisation and processes in the world of employment (even if only in terms of the gradual reduction in the working week), would seem to be more than just attempting the impossible.

Finally, it is essential to mention that during the period examined, two school systems existed in France with radically opposed aims and organised to meet two different principles. The foremost was secular, public and mandatory, based on the Ecoles des Frères set up by Jean-Baptiste de La Salle, and was formally shaped by the Jules Ferry laws (between 1880 and 1886). Some 3.5 million children were provided with schooling which included physical education for all. The second system was Catholic, private and fee-paying, with a bare, 150,000 children being catered for at the beginning of the twentieth century: it incorporated sports. While the former sought to provide schooling from 1882 for both boys and girls without discriminating, the same 
cannot be said of the latter since, as is explained below, it was not until 1924 that the content of the baccalauréat curriculum finally became identical for both sexes in Catholic as well as State schools. Although sport was present in the more numerically limited system which had the more significant impact, greater attention is given in this paper to State physical education than to sport. We first attempt to explain the changes in the place of women in the educational system and in society and in the writings (most often by men) on women's sports and physical education under the Third Republic (1870-1939) in France. This period covers significant movements affecting the history of the thought processes that produced the modern and contemporary backdrop to this particular field.

Furthermore, as it is not possible in the space allotted to this article to cite all archives and sources that have been helpful to us in our research, the bibliography lists the specific French language documents quoted in this paper. Information is drawn from works and articles in widely diffused school manuals on hygiene and morals, and from works written for teachers of PE\&S.

\section{Theoretical Preamble}

Gymnastics was born largely from the consideration of the body and from writings on the body as a model of a simple "natural energy" machine. The arrival of gymnastics in the Classical Age is contemporary with the initial phases of commercial capitalism and the obsolescence of traditional agrarian and feudal models (see Gleyse, 1997). Energetic sports and gymnastics discovered their archetypal founder in the factory and artificial energy machines and more generally in industrial capitalism (see Gleyse, 1997; Rauch, 1983; Vigarello, 1978). These activities are the corollary of the development of manual labour and the bourgeoisie after the French Revolution of 1789 and above all from the development of secondary industrial production throughout the 
western world (Brohm, 1975 and 1976, Defrance 1987, Guttmann, 1979, Pociello, 1981). That they began in England, which was the most advanced country in terms of secondary industrial development, provides a good analytical marker for the process (a sort of copying occurred between the way power-demanding work developed in secondary industry, and became increasingly standardised and carefully timed and power-demanding, standardised and timed sports practices). However, their subsequent general accessibility in France coincided with the great reduction — nearly $50 \%$ - in the length of the working week that occurred during the first half of the twentieth century. In fact, to be able to take part in sports activities, time has to be available.

The first forms of euphemisation of physical practices, the gradual transition from a dialogue about "strength" to one based on "energy" and then on "gracefulness" the determinant references described by Christian Pociello (1981) - seem to be very much the outcome of the early development of the service sector. From this, the generalisation of feminine physical practice in France is effectively contemporary (1970) with the issue of service sector industrial production and the massive increase in non-domestic employment among women (Tartakowsky \& Willard, 1981, p. 123).

The high profile hypothesis of this research is thus that women could only be integrated into the productive world when the world of production, with the subsequent division of labour, made such employment possible; in other words, when it became physically less demanding or even information-based (though of course, it could be linked to struggles such as of the suffragettes before 1900, and the "garçonnes" or urchins after the second world war). This process, as a sort of rather deformed reflection or anamorphosis, can be seen in the dialogue on bodily practice. In much the same way, the Republican scholastic system took no responsibility for educating girls until this was necessitated by the requirements of industrial production methods. At the same 
time, the education of girls and their inclusion in the practice of physical exercise led to their becoming integrated into the productive world. The physical education of women in the institutional meaning of the term was thus inseparable from their overall admission to schooling and the latter did not really occur until 1880 following the Camille Sée Law of 21 December $1880^{1}$. Consequently there was a dialogue (or dialogic to use Edgar Morin's expression - Morin, 1988) between the productive world, school, and the discourse on the feminine practice of exercise.

\section{Women's Education in France - a benchmark for the spirit of the times}

When in 1862 and with the support of the Empress, Julie Daubié passed the baccalaureate in arts in Lyon after having been refused permission to sit it in Paris, she became the first woman to obtain this accolade (Parias, 1991, p. 123). In the same year, Madeleine Brès, also with the support of France's First Lady, was the first woman allowed to undertake medical studies (Parias, 1991). These two cases are clear symbolic markers of an important shift in the position of women in society. Until the middle of the nineteenth century, before the Falloux $\mathrm{Law}^{2}$ of March $15^{\text {th }} 1850$, there was complete segregation of girls who did not then benefit from public schooling (Parias, 1991). It was essential for young women, according to an expression of Mgr Dupanloup to be raised "in the lap of the Church" (Parias, 1991, p. 113). The State had almost no involvement in female education. At the beginning of the nineteenth century the level of literacy among women was generally greatly inferior to that of men.

From 1842 onwards the gradual introduction of teaching colleges for women led to the development of state education for girls (Lelièvre, 1991, p. 120). The Paul Bert Law (August $\left.9^{\text {th }} 1879\right)^{3}$ and then the Ferry Law (March $\left.28^{\text {th }} 1882\right)^{4}$ made primary education obligatory for every child: 
Article 4: Primary education is obligatory for children of both genders from the age of six years: it may be provided in primary or secondary educational establishments or in public or free schools, or in the family by the father himself or by any person he chooses. (Lelièvre, p. 95)

The culmination of these major trends may be discerned in the decree of March $25^{\text {th }}$ 1924 which aligned the female secondary school syllabus with the male syllabus and by so doing included access to the baccalaureate for girls, even though it was presented only as an option ${ }^{5}$. By 1936 women constituted twenty five percent of those passing the first part of this diploma. These discursive and institutional events, however, would not have taken place without the changes that were occurring in the world of labour (paid work). In this respect, reference can be made to Braudel's view of history as expounded in his Civilisation matérielle, économie et capitalisme (Braudel, 1979, Material civilization, economics and capitalism) or more simply, in Foucault's archaeology and the history of anthropology. Schools, it seems, were beginning to take female education into account at the most advanced levels and when incorporating women into the socioeconomic system became a necessity. The corollary of providing women with schooling was their genuine and increasing involvement in the field of physical exercise. In these terms, several structural explanatory hypotheses may be developed.

On the one hand, the birth rate fell considerably between the mid nineteenth century and the beginning of the twentieth. There was a total of 998,500 births in 1860 this figure dropping to 746,700 in 1913 . Only after the population reduction caused by the 1914-18 war was there a slight increase. The reduction in birth rate was slightly compensated by the reduction in death rate, which fell from a total of 894,800 deaths in 1865 to 723,700 in 1913 . It might be thought that the employment of children and women was related to this factor (even though such illegal employment had existed 
previously). What is even more apparent is that most of the energy used in the productive world was still either animal or human - 94\% in 1850 compared with $4 \%$ a hundred years later (Beltran \& Griset, 1990, p. 253). There was an increasing need for hands to meet the requirements of ever-increasing industrial growth. It must also be remembered that, in this strictly capitalist economy, the work of women and children was less well remunerated than that of men, and therefore provided a better return.

On the other hand, those trades and sectors of the economy that developed most strongly with industrial mechanisation were in the secondary and service industries. In 1850 , the activities that required the most physical strength and the least intellectual capacity, those in primary industries, employed some $54 \%$ of the total working population but had reduced to only $36 \%$ by 1931 in inverse proportion to the secondary and tertiary sectors. The number of people employed in the service sector increased from $21.3 \%$ to $30 \%$ of the working population and those in secondary production from $24.3 \%$ to $34 \%$ (Tartakowsky \& Willard, 1981, p. 180). These trends are even more pronounced for women's employment ${ }^{6}$ : female workers dominated light secondary industry.

It is sufficient to examine the employment of spinners in the textile industry in the North of France, Lyon and the Cévennes to appreciate that development in this sector doubled with the feminisation of employment. From the time of the First Empire (Tartakowski \& Willard, 1981, p. 148) the growth in size of major state offices also made possible the non-domestic employment of women. The link between the development of schooling and of secondary light industry and tertiary industry is perfectly explained elsewhere by Claude and Françoise Lelièvre (1991, p. 135,). 
Nevertheless, the determinant factors were surely that the greatest requirement existed and the greatest opportunities were available in the scientific and the intellectual sectors. As S. Kuznets writes, when speaking of the nineteenth century:

Modern economic growth can be defined in the following manner: the extension of a system of production in the general meaning of the term, based on constant progress in scientific application; in other words, on an organised system of controlled knowledge. (Tartakowski \& Willard, 1981, p. 180).

In this field, as in the more general services sector, it is patently obvious that the work of women was at least as productive as that of men. Proof of this can be seen in the number of women doctors and researchers by the beginning of the twentieth century: Marie Curie (1867-1934) was the first woman to obtain a chair at the Sorbonne, Jeanne Chauvin, the first woman advocate and Marie Long-Landry, the first woman doctor to be appointed head of clinic at Salpetrière, the principal medical school in Paris. In the 1920s, there were some hundred women doctors and fifty advocates and journalists (Lelièvre, p. 57).

Once women became involved in the production process, they claimed equal rights with men and began similarly to take up exercising. They also demanded to be included in competitive sport. This was the case, although limited to the middle and upper social classes (see Shilling, 1993; and Bourdieu, 1999), of the suffragettes in the latter part of the nineteenth and beginning of the twentieth century in England, the United States and France. In addition, the fact that the movement began in England in 1865, the country where industrialisation had occurred first, tends to corroborate the idea of a link between industrial production, the practice of physical exercises and the emancipation enjoyed by some women. This movement did not of course, affect all social classes in 
the same way and what was manifest among the culturally favoured middle and upper classes probably did not affect the working classes until nearly a century later.

Women had gained the right to vote by 1920 in most European countries. In France, this right was not granted until the ruling of $21^{\text {st }}$ April 1944, even though, in local elections from 1925 onwards, the Communists put forward female candidates from among the working class population: their election was subsequently invalidated. Elsewhere, involvement in economic life led women of the upper classes to transform their way of life and even their corporeality.

The novel by Victor Margueritte appearing in 1922, La Garçonne (The Female Boy) is a perfect example of this. Monique Lerbier, the heroine, dresses in short skirts or wears trousers, cuts her hair, smokes and proudly proclaims her sexual independence. A million copies of the work were sold over the next seven years following publication, proof not only of the social importance accorded to the phenomenon but also of the scandal it aroused and the debate that ensued. After his work was published Victor Margueritte was deprived of his coveted award of the Legion of Honour - a rarely used sanction. The shift was not achieved without casualties.

Of course, the change in status and increase in power was not obtained without overcoming intransigent male resistance. In 1880, Le Gaulois newspaper declared:

High school for girls? Why not the barracks for girls too? The French girl, raised under the vigilant aegis of the family, is carefully protected from a tomboy's education and the brutalities of science. She grows up in sweet ignorance of worldly affairs to attain the candid serenity of a young woman with that delicious flowering of modest desire and those outbursts of idealistic bounty that will later turn into wifely love, the devotion of a woman and the self-sacrifice of a mother [...] all this will disappear! Girls will be eradicated. [...] Science and the state will snuff out their childhood illusions. They will 
learn everything, even impurity. They will even lose their virginity before adulthood.

(cited by Lelièvre, 1991, p. 114).

Even Jules Simon, a committed republican, yet well known conservative, reacted against the new position achieved by a few women:

I contend that it is quite useless to teach girls practical chemistry. [...] In fact, to undertake philosophical study, the mature, previously prepared mind of a man is essential. (Lelièvre, 1991, p. 118).

Both in sport and more generally in the field of physical exercise, there were signs that men were becoming worried by their relative loss of control over the female sex. And so often power is involved in physical exercise as it is in education. Jules Ferry had thoroughly understood this:

He who controls the female controls everything; firstly because he controls the child and next because he controls the husband." ${ }^{7}$

It is clear there was, at the very least, a deep rift between the traditional image of women and the social position they attained by their new deal in employment and schooling and through their own militancy. All these discursive and other events interacted, as we shall now see, with the world of physical education and sport.

\section{The Discourse on Physical Exercise by Women. Establishing a "Social Fact"?}

\section{The first expressions}

Before the paper by Clias Callisthenics or natural somatology applied in the physical education of girls (Clias, 1843) appeared in 1843 - repeating point by point the suggestions made previously for male exercise — and more significantly the work of Jean-Baptiste Fonssagrives in 1869 Physical education for girls, it seemed that there was no treatise in French of any importance devoted specifically to female physical education. The various nineteenth century medical encyclopaedias bear no sign of it, 
either in the papers themselves or in the bibliographies, neither under the heading "exercise" nor under "gymnastics". The chapter devoted to these subjects by D. Barbier in "Le Pancoucke", in 1817 (Barbier, 1817, p. 583), is well known among medical historians but makes no reference to female practice, and the same is true in articles by Rostan and Pravaz in the Répertoire général (Rostand \& Pravaz, 1836, pp. 450-476) published by Bechet in 1836. And even in 1886, the Medical dictionary edited by Dechambre and Lereboullet (Dally, 1886, pp. 792-869) makes no mention of the subject.

In short, Jean-Baptiste Fonssagrives would seem to be something of a precursor in the matter. More specifically in his work, the "fifth interview" (Fonssagrives, 1869, pp. 107-125) was entirely devoted to the topic of "girl's gymnastics", and was particularly innovative for its time. It is worth recalling that, when the term "physical education" first made its appearance in the titles and contents of papers in the middle of the eighteenth century, it was used to mean the development and maintenance of major organ functions and was not limited merely to efficient movement. The terms "exercitation" (old French), "exercise" and occasionally "gymnastics" covered the sense implied by the expression physical education in use today. In any case, for JeanBaptiste Fonssagrives, gymnastics was an indispensable element in girls' physical education. Yet, as we are to see a little later in the case of sport, it was not just any gymnastics that were thought to serve the well-being of girls but limited, reasoned and precise gymnastics:

There is a delicate balance; a little exercise fortifies, a lot exhausts. (Fonssagrives, 1869, p. 117)

In other words, abuse of exercise was criticised here as elsewhere: 
Here $[\ldots]$ the admirably pertinent words of Montaigne come to mind: 'The archer who overshoots fails just as he who undershoots the target.' We overshoot regularly in gymnastics, and the teachers who are responsible for exercises contribute to this. (Fonssagrives, 1869, p. 117)

Hence the necessity, in the first instance, to distinguish genuine medical gymnastics from the non genuine, the preserve of the acrobat:

There is a generally-held idea which must be corrected, that confounds gymnastics and acrobatics and mistakenly measures the efficacy of the former by the facility with which children climb a smooth rope, climb with hands alone and execute a range of movements on the wooden horse, trapeze, and parallel bars. (Fonssagrives, 1869, p.

This type of gymnastics was definitely not suitable for girls:

Home gymnastics are sufficient for girls, but they must persevere diligently with the practice. (Fonssagrives, 1869, p. 120)

In female gymnastics as elsewhere, and as had been the case in male gymnastics since the beginning of the nineteenth century, it was the precision, consistency and standardisation of movements so invaluable to society and to the secondary industries, that were favoured. Thus, in terms of their theoretical basis, such gymnastic exercises were really indistinguishable from those performed by boys:

Exercises must be sensibly graduated, and, if there is an apparently unusual health issue, the doctor must intervene. (Fonssagrives, 1869, p. 121).

This argument can doubtless be applied to the overall structure of the work place, and also to the mode of control and monitoring described by Michel Foucault (1975) and others (Brochhoff, 1972) in terms of the micropower exercised generally 
on the entire population. Schreber's manual of 1856, well known to historians, was cited as an organisational model:

Schreber's manual provides for the graduation of each exercise using a three figure code, with the first figure representing the number of movements by which adults should commence. (Fonssagrives, 1869, p. 121)

Here as elsewhere it was a matter of the instrumental rationalisation of movement on the simple "mechanical" or energetic model that could be found in school and factory by the end of the nineteenth century. From this point of view, women had no reason to escape from the overall trend. The body was brought to standard by being "instrumentalised". Where legs were too frail, they would be muscled up; if it were the chest, respiratory gymnastics might be prescribed. So there was a determination to rationally re-establish the bodily balance where it was considered disturbed. With this same aim of controlling time and space, and the psychosomatic balance, one of the purposes devolving from gymnastics and already raised by Rousseau (1762) ${ }^{8}$ was to keep young women (at first upper classes women) from masturbating by diverting their sexual urges. Finally only young children were to escape from this excessive process of corporal regulation:

Before the age of eight, there is only one form of gymnastics that is suitable for girls and this is games, running or taking a stroll and gymnastic exercises that have an appeal as stimulant and freedom for conditioning. Only sick children must yield at an earlier age to movements imposed in the gymnasium. For them, gymnastics provided first recourse medication. (Fonssasgrives, 1869, p. 116)

But as far as women in general were concerned - and this is a discourse that was being repeated constantly by the beginning of the twentieth century - gymnastics had not only a purpose for them as individuals but also for the nation as a whole: 
Without gymnastics, and I cannot repeat this often enough, there would be no physical education for girls, no general fitness, no pleasing proportions, no aptitude for efficient maternity, and no capacity to provide robust offspring. This is the seriousness of its importance. (Fonssagrives, 1869, p. 125).

With this in the background, it is understandable that the preoccupation with female physical education or gymnastics became more or less permanent from the end of the nineteenth century. In a way the physical education of young women was seen as the education of the nation and its descendants. In fact, it was implicitly a matter of seeking uniformity, with the objective of obtaining higher productivity from the female body as much as from the male body. However, while at the very end of the nineteenth century women were almost always mentioned in the literature on P.E. and gymnastics, they were set clearly apart since any paper written up to the end of the Third Republic makes distinct references to women's practices and men's practices.

\section{Authorised and Forbidden Practices. The limits of femininity.}

When, in 1921 the English Football Association forbade the lending of pitches to women football players under the pretext that,

The sport of the round ball is neither decent nor graceful for women and finally it is too brutal and dangerous for them. (Le Miroir des sports, 1921, p. 369)

it was perpetuating a controversy that had been current for some time in France as numerous writings provide evidence, in general right throughout the Third Republic. Pierre De Coubertin himself took up the issue as he asserted that: "a female Olympics competitor would be uninteresting, unattractive and improper." ${ }^{9}$ It is possible to see the last reverberations of this debate in the voluminous Traité d'Education Physique (Treatise on Physical Education) under the editorship of Marcel Labbé (1930). In this treatise, the forceful article on "female gymnastics" (Jeudon, 1930, pp. 539-578) by Dr 
Robert Jeudon, provides a synthesis of the various positions held at the time, a position may be summarised as follows: rational and artistic gymnastics are suitable for women, whereas sport, when it becomes over competitive, should be banned. For women the two extremes - laziness and serious competitiveness - are both rejected:

Today, despite the real but haphazard evolution that the significant sports movement, strengthened by the war, has imposed on us, the situation is almost as deplorable as it has been profoundly modified. Young women are now divided in this matter into two categories. Those in the first category continue the tradition of their grandmothers, meaning they do nothing. Those in the second, avid for the easy glory acquired from sport, devote themselves body and soul, primarily to competitive sports, without taking into account their personal abilities, without rational training, without a program and without physiological monitoring. (Jeudon, p. 539-540).

The supporters of rational gymnastics made the same reproach of male sport at the close of the nineteenth century. Here, as elsewhere, physical activity was to serve the purpose not of letting desires be expressed but of instrumentally rationalising the bodily fitness required both generally and for the production process in particular. The last words quoted above are unequivocal. It was a question of rational training, programming and physiological monitoring: in other words, of obtaining the fittest energy resources in women as well as men. The female does, however, have a special place in the system because she brings children into the world:

The female is designed above all for procreation; consequently, the culture of the female body is at least as important as that of the male body, because the maternal physical qualities, in addition to facilitating eugenics, are transmitted to the child. The supreme purpose of the female is to improve the well being of posterity. By cultivating the physical and physiological value of the female, the whole nation will be improved with her. (Jeudon, 1930, p. 540). 
This point of view, well known to English readers, is a preoccupation of the middle and upper social classes (Defrance, 1987, Bourdieu 1979) concerned about the possible adverse effects arising from too much idleness.

Sport thus perceived as a bodily disorder, could not easily play a role in the particular process of eugenics (Foucault 1975, Gleyse 1995) to underpin instrumental rationalisation, it could not be bodily culture. But what was deemed to be true in the particular instance was more generally the case for both sexes:

Sports and the female. In the course of the last few years this question has been the subject of interminable, heated discussions, which, while deserving to be fully developed, seem to us to have no place in this paper. Let us be content here therefore with a summary of the general line to be followed which the experience of some years [...] seems to consider as rational. It is incontestable that female sport suffers from the same disease as other types of sport: the abuse of public competition, the large increase in the number of championships. (Jeudon, 1930, p. 573).

The urges of both men and women were questioned in the same way. This approach was again very specifically expressed in a manual of morals in the late thirties:

But here as in everything else, it is important to set reasonable limits 'il faut savoir mesure garder'. It is good to avoid excessive training [...]. The body must not be treated like an old rag. There is no reason to behave like a tyrant. (Ab Der Halden, 1935, p. 19).

Women, however, remained the particular target of this injunction as the text offered as an illustration is entitled: "Emily or the sports enthusiast", which quite simply discredits intensive female sports practice. ${ }^{10}$ Nevertheless, in the end the writings on the female were only a representation of a much wider discursive formation. They were merely a symbolic benchmark. As an example, during the Roaring Twenties, the exploration by the Miroir des sports (in analysing papers published from 1921 to 1923) 
discovered that while a significant number of articles were devoted to female sport, they were nearly all concerned with sports that might be described as "graceful" or "sports of strategy" or even "mildly energetic", according to the determinants of Christian Pociello (1981) discussed above. When this was not the case, when it involved "violently energetic" sports or "tests of strength", the place of women was hotly debated. In any case, in the course of the three years under examination ${ }^{11}$, the only article that devoted two full, laudatory pages to a female sport was entitled: "Female physical culture: harmonious movement." (Le Miroir des sports, 1921, pp. 298 and 299) In short, in France, those activities deemed to correlate in sociological terms with information handling (service sector) forms of work were highly valued. This has been successfully demonstrated by several authors today (see Gleyse, 1995, Pociello, 1995, Travaillot, 1999). It concerns those activities where reflexes and gracefulness are more important than strength or energy. During this period an increasing number of women were in paid employment (see Tartakowski \& Willard, 1981) they comprised $73 \%$ in the service sector and light secondary industry (textiles) which became dominant at the end of the twentieth century (making up two thirds of all employment in France at the end of the twentieth century compared with a third at the beginning).

Moreover, the number of articles devoted to women in specialist sports journals, or more generally in the literature, was evidence of their complete integration in the nondomestic production process. As an example, an investigation by the journal La Vie au grand air $^{12}$ (Life in the open air) some twenty years earlier, confirms the total absence of articles devoted to female sport, even though a drawing of a sportswoman (a tennis player) graced the cover of the Miroir des sport (Sporting Mirror). Here again, the same process could be found as in the educational system and, of course, in the world of labour. 
Virtually alone, Georges Hébert (1875-1957), a significant and influential personality in physical education in France at the time, anticipated the future, or at least showed his awareness of the situation in schooling and employment when he made the explicit statement that: "The natural doctrine applies as much to girls' education as it does to boys'." (Hébert, 1936, p. 9), and by contending that: "Women, in a word, can become athletes." (p. 9). He was to be criticised on this point in the previously cited Traité d'éducation physique, where he was reproached for making women masculine:

All Hébert's action extends the making of a man and as Montaigne has said, 'to toughen soul and body.' In the female, he is developing the same qualities and extending women to achieve a virile type too. (Cambrier, 1930, p. 179).

Actually, the position of Hébert was ambivalent and it evolved over a quarter century as in 1911 he suggested in Code de la force (Code of strength) an "adaptation of competitions for subjects of the female sex." ${ }^{13}$ However, the sentence which opens the chapter shows that Hébert, in contrast with most other authors of the period, had understood that in terms of the demands of the new booming socio-cultural and socioeconomic world (light industry and the service sector) women possessed the same potential as men:

The young woman who is developed and trained in a way that is as complete and extending as it is for a young man will be able to measure up as more or less his equal in all competitions. But the social and family role of the female, her life style, the way she has been brought up, her mentality and aspirations, all of which have to be taken into account, impede her development and do not predispose her to demonstrations of strength. (Hébert, 1911, p. 106) 
In 1919, when writing Muscle et beauté plastique féminine, (Muscle and plasticity in female beauty) he was one of the first to try to change this mentality. He is explicit about this in the foreword to his work:

This book is addressed to the generation that is growing up: to girls wanting to emancipate themselves through exercise from the pain their elders suffered, to young mothers who, having understood the importance of physical education, would above all like their daughters to become beautiful, strong and healthy beings and not delicate dolls. (Hébert, 1919, p. 6).

The introduction of Palestres was to put the finishing touches to this visionary logic. In 1913, a much less well-known doctor, Dr Francis Heckel, in his voluminous (624 pages) Traité de culture physique (Treatise on physical culture), was one of the few to share Hébert's point of view and to align himself with women in the battle for the right to take up exercising:

Girls must undergo exactly the same physical education as boys from puberty. [...] It should not be thought that women are physically weaker than men and less capable of bodily exercise. While it is often the case today, this is simply the outcome of their inadequate physical education. [...] when they undergo a full, rational physical education, they are capable of attaining very great vigour and much more speed, suppleness and agility than men. (Heckel, 1913, p. 502).

These last qualities were exactly those that were the most prized in the new labouring world, following developments instigated by Taylor and Ford. Here again, it is clear that a discourse on the practice of exercising has become integrated into the major organisations and institutions of the time or, to express it as did Michel Foucault, incorporated in an épistémê. The final point in the last quotation on attaining vigour, speed and suppleness could also be taken to apply to men who neglected to exercise. 


\section{The Female Shape. Another world, another body.}

When Lagrange wrote in 1888:

A good number of observers have remarked how elegant and regular is the height of women among people who carry water on their heads when they fetch it from the spring; how, by comparison, it is variable in those countries where the weight of the pitcher is borne on the shoulders. The women of Tenerife, according to a traveller visiting the island, are remarkable for their elegant height; they are astonishing too for their degree of dexterity. (Lagrange, 1888, p. 310),

he was providing evidence of a change in the view of female corporeality associated with physical labour. What could be perceived regarding the male in the contrasting imagery of the statues of Hercules and the fighting gladiator in the Farnèse villa (Andrieu, 1992, pp. 225-240) here found a direct extension in a feminine example. Of course, authors at the beginning of the twentieth century, depending on whether they were in favour of intensive female practice as Georges Hébert, or against it, did not all espouse the same model. Some, at the time of Lagrange, remained very much attached to the past. Such was the case of Emile Couvreur, although his thinking showed evidence of considerable ambivalence:

Under the effect of her physical work, little by little the countrywoman loses her femininity $[\ldots]$ it seems one is dealing more with a man than a woman. This is not the purpose of the exercise that should be advised for young women. (Couvreur, 1890, p. 319).

This critique can of course be cross-referred with the work of Pierre Bourdieu (1999) or Shilling (1993) analysing the situation in terms of the class conflict, but it is not the purpose of this article which is concerned to define a modification in the 
épistémê involving the female body within the discourse on the practice of exercise. This opinion was, however, put into perspective by another:

It should not be thought, despite what is said at the beginning of this chapter, that violent exercise is absolutely incompatible with the physical constitution of women. (Couvreur, 1890, p. 319).

Georges Deménij (1850-1917), one of the most influential personalities in physical education. in France in the late nineteenth and early twentieth centuries, also had a highly ambivalent attitude towards femininity:

Educational procedures must be adapted to the sexes: this requirement is imposed by habit and prejudice. Women [...] have the responsibility to be strong to fulfil their role [of being a mother], they must also be graceful in order to please and they must be enlightened too about their function. (Demenij, 1902, p. 37)

For this author as for Georges Hébert, the visible shape had become less important than the internal form. Because Demenij was far more preoccupied with physiology than with mechanics, he could accept a new way of looking at the female body. His findings did not differ from those of Hébert, who, from the non-scientific or even antiscientific viewpoint, espoused the same position. It was the energy potential of the body that was fundamental for Georges Hébert and not its external form.

Once this point of view was adopted, women were no longer viewed any differently from men, at least by the majority of the proponents of physical education at school. This was not the case for proponents of sport.

Nevertheless, overall, in writings from the beginning of the twentieth century, another form of female body had won acceptance over that which had previously dominated. Thus, though he was little in favour of intensive physical education for girls, it was possible to read in Henri Hœnig's work: 
Women are made above all for procreation; consequently, the culture of the female body is at least as important as that of the male body, because the maternal physical qualities, in addition to facilitating eugenics, are transmitted to the child. The supreme purpose of a woman is to improve the well being of posterity. By cultivating the physical and physiological value of a women, the whole nation will improve with her (Jeudon, 1930, p. 540).

Young women must therefore practice physical exercises [...] they will battle [by doing so] against portliness, bodily deformity and often against skinniness too, which will ensure that they long retain their fitness and plasticity (Hœnig, 1911, p. 107).

The iconography suggested by Georges Hébert is, from this point of view, the most revealing. In various of his works, photographs of part-naked young French and African women abound. Their forms are not at all like those to be seen in the paintings of Renoir (particularly during Renoir's early period: Les grandes baigneuses - The Bathers, 1865-85), or those depicted even earlier by painters of the classical period, which were quite round and plump. On the contrary, in Hébert's photographs the muscles of the subjects are apparent, their deltoids, the vast circumference of the quadriceps, the trapezius and biceps stand out instead of being hidden under a chubby covering. For women as for men, fatty tissue had become synonymous with poor health, lack of physiological fitness ${ }^{14}$ and consequently of a reduced productive capacity. Hébert lauded the new appearance as more compatible with the contemporary socio-economic and scholastic environment:

Young black African woman, where the magnificent development of the torso stands comparison with Venus [...] The admirable proportions of this Venus, the beautiful, strongly developed thorax and the perfect line of the pelvis, what a marvellous ideal for the French mother! (Hébert, 1919, p. 187). 
The official discourse, though, at about this time, did not take the same line as Hébert: the Règlement général méthode française (French general method regulations), applying in the army and in all scholastic establishments in France after 1925, took a rather different stance:

Thus the aim is not to develop a woman's muscles but rather to take care not to expose her to the same physical education procedures as those reserved for young men. (Règlement Général, 1925, p. 16).

Women who made up the intellectual elite, on the other hand, had fully assimilated the new (production oriented?) canons of beauty propounded by Hébert. A study entitled Femme, cultive ton corps (Woman, cultivate your body), appearing in 1933 was categorical on the point:

Why should we undertake physical culture? Because we must be beautiful, or strive to become so, because we must force ourselves to preserve our beauty, our youthfulness, as long as possible and without making the physical movements that are the source of beauty, we have no chance of fulfilling with great success, our social role, that of being mothers. (Vincello, 1933, pp. 25-26)

The key phrase had been uttered: 'eternal youth'. This was the term that for a while justified the new corporeal model of femininity. Modernity, in its hegemonic development and its vague desires for increased corporal uniformity, fixed on the model of an almost androgynous young woman ${ }^{15}$ as the identifying mythology. In other words, it fixed on a reproductive and productive female and not merely a procreative female model. The model was to become ever more youthful and be an obsession for some women throughout the whole of the twentieth century

\section{Conclusion}


The writings on women, despite their ambivalence, reveal differences and contradictions which reflect the major trends of modernity (see Gleyse, 1997), the standardisation and uniformity of bodily practice - that some term "world-embracing" and others 'universal'. In addition, it was not only the body but also the mind that came under its influence. The history of girls' scholastic education, as the history of their bodily education, enables this dynamic to be understood.

The world of feminine bodily practice enters into a dialogue with the society in which it is assimilated. With industrialisation, 'Women' were brought into conformity with those standards that were most beneficial to the production process. In this sense, the female body had to look more and more like the male body ("women can be athletes," said Georges Hébert), the two models had to match. This at least was the project undertaken by the proponents of female physical education. 'The Woman' who entered the production process via light secondary or service industries, through her schooling had to construct not only a reproductive body but also a productive body.

After heated debate during the 1930s, the model of beauty for women who wished to take part in physical education. (rather than in sports education) was that of the young and well muscled, and corresponded perhaps to the beginning of the requirement for corporeal standardisation and uniformity (see Matthews, 1987). The extensive writings on physical education provide ample evidence that this imagery had become accepted "social fact". The body that physical education would like to manufacture became an increasingly androgynous model, even though some dispersed pockets of resistance raised objections to this interpretation (among medical doctors and De Coubertin himself). Furthermore, in France under the Third Republic, the world of physical education. seemed more inclined to find a place for this model than did the world of sport. 
This paper is not the final word on the subject; it is concerned merely to shed new light on the history of physical education and sport for women in France under the Third Republic ten years after Richard Holt's work. Our aim, without claiming to be in any way exhaustive, is to provide an overview of the areas explored by those working in the French language. Perhaps it will also enable a clearer understanding of why the debate is still current today between the partisans of mixed physical education (at present a predominantly male point of view) and the partisans of a physical education where there is positive discrimination in respect of girls (a predominantly female point of view). The institution of physical education which has been entirely conceived by men in a male world still has great difficulty in making a place for girls both in terms of practice modes and in the choice of the practice itself. 


\section{References (English language)}

ALLEN, J. B. (Winter 1990) Sierra Ladies on Skis in Gold Rush California, Journal of Sport History, 17 , pp. 347-353.

ARCHER, J. \& MC DONALD, M. (1990) Gender and roles and sports in adolescents girls, Leisure Studies, 9, pp. 225-240.

ATKINSON, P. (1992) The Feminist Physique: Physical Education and the Medicalization of Women's Education, in : Mangan and Park (eds.), From Fair Sex, pp.42-45.

BIRRELL, S. \& Richter D. M. (1987) Is a Diamond Forever? Feminist Transformations of Sport, Women's Studies International Forum. 10, pp. 395-409.

BIRRELL, S. (1988) Writings on the Gender/Sport Relationship: From Women in Sport to Gender Relations, Exercise and Sport Science Review, 16, pp. 459-502.

BIRRELL, S. (December 1987) Women Athlete's College Experience: Knowns and Unknowns, Journal of Sport and Social Issues, 11, pp. 82-96.

BIRRELL, S. 1 COLE, C. L. (1990) Double Fault: Renee Richards and the Construction and Naturalization of Difference, Sociology of Sport Journal, 7, pp. 1-21.

BRADBERRY, B. (1987) Women's History and Working Class History, Labour/ Le Travail, 19, pp. 2343.

CLARKE, G (1998) Queering the Pitch and Coming Out to Play: Lesbians in Physical Education and Sport, Sport, Education and Society, 2, pp. 145-161.

EVANS, J. DAVIES, B. \& PENNEY, D. (1996) Teachers, Teaching and the Social Construction of Gender Relations, Sport, Education and Society, 2, 1, pp. 165-185.

FLETCHER, A. (1999) Gender, Sex and subordination in England, 1500-1800, (Yale University Press).

HARGREAVES, J. (1994) Sporting Females, (London, Taylor \& Francis Books Ltd).

HARGREAVES, J. (2000) Heroines of Sport, (London, Taylor \& Francis Books, Ltd).

HARVEY, J. and SPARKS, R. (1991) The Politics of the Body in the Context of Modernity, Quest, 43, pp. 164-189.

HOLT, R. (1985) Social History and Bourgeois Culture, Comparative Studies, Society and History, 27, pp.13-26.

HOLT, R. (1985) The Bicycle, the Bourgeoisie and the Discovery of Rural France, 1880-1914. British Journal of Sports History, 2, pp. 127-139.

HOLT, R. (1991) Women, Men and Sport in France, c. 1870-1914: An Introductory Survey, Journal of Sport History, 18, pp. 121-134.

KIRK, D. (1998) Schooling Bodies. School practice and public discourse. 1880-1950, (London, Continuum International Publishing Group).

LENSKYJ, H. (1983) We Want to Play. We'll Play: Women and Sport in the Twenties and Thirties, Canadian Woman Studies, 4, pp.15-18.

LENSKYJ, H. (1992) Whose Sport? Whose Traditions ? Canadian Women and Sport in the Twentieth Century, International Journal of the History of Sport, 9, pp. 141-150.

MATTHEWS, J. J. (1987) Building the Body Beautiful, Australian Feminist, Studies,5, Summer, pp. 1734. 
MELLOR, P.A. \& SHILLING, C. (1993) Re-forming the body, (London, Sage).

RENOLD, E. (1997) All They've Got on Their Brain is Football. Sport, Masculinity and the Gendered Practices of Playground Relations, Sport, Education and Society, 1, 2, pp. 5-25.

SHILLING, C. (1993) The body and social theory, (London, Sage).

SCRATON, S. (1987) Gender and physical education: ideologies of the physical and the politics of sexuality, in: L. BARTON \& WALKER (Eds) Changing Policies, Changing Teachers (Milton Keynes, Open University Press).

SCRATON, S. (1992) Shaping up to womanhood. Gender and girl's physical education, (London, Open University Press, Gender and Education).

SCRATON, S. (1993) Equality, Coeducation and physical education in secondary schooling, in:. EVANS (Ed.) Equality, Education and Physical Education (London, Falmer Press).

SYNNOT, A. (1993) The body social, (London, Routledge).

VERTINSKY, P. (1988) Of No Use Without Health: Late Nineteenth Century Medical Prescriptions for Female Exercise Through the Life Span, Women and Health, 14, pp. 89-115.

VERTINSKY, P. A. (1994) Sport History and Gender Relations, 1983-1993: Bibliography, Journal of Sport History, 21, pp. 25-58.

WRIGTH, J. (1997) The Construction of Gendered Contexts in Single Sex and Co-educational Physical Education Lesson, Sport, Education and Society, 1, 2, pp. 55-73.

\section{References (French language)}

AB DER HALDEN, C. (1935), Leçons de morales. Ecoles primaires supérieures (Paris, Armand Colin). ANDRIEU, G. (1992) A la recherche d'un modèle ou deux de surhomme, in: RENE B.X. (ed.) L'Education physique au XXe siècle en France (Paris, EPS), pp. 227-240.

ARNAUD, P. \& TERRET, T. (1996) Histoire du sport féminin, Tome I et II (Paris, L'harmattan).

BARBIER, D. (1817) gymnastique in: PANCOUCKE (Ed.) Dictionnaire des sciences médicales, vol. XIX, (Paris, Panckoucke), pp. 583-588.

BEAUDELOT, C. \& ESTABLET, R. (1992) Allez les filles ! (Paris, Seuil).

BELTRAN, A. \& GRISET, P. (1990) Histoire des techniques aux XIXe and XXe siècles (Paris, Armand Colin),

BERLIOUX, M. (1968) D'Olympie à Mexico (Paris, Seuil).

BOIGEY, M. (1922) Manuel scientifique d'éducation physique (Paris, Masson et Cie).

BOIGEY, M. (1934) La cure d'exercice (Paris, Masson et Cie).

BOURDIEU, P. (1979) La Distinction (Paris, Minuit).

BOURDIEU, P. (1999) La domination masculine (Paris, Liber).

BRAUDEL, F. (1979) Civilisation matérielle, économie and capitalisme, XVe-XVIIIe siècles (Paris, Armand Colin).

BUI-XUAN, G. \& GLEYSE, J. (2001) L'Emergence de l'Education physique. Georges Demenij et Georges Hébert, (Paris, Hatier). 
CAMBIER, M. (1930) L'hérédité en éducation physique, in: LABBE M. (1930), Traité d'éducation physique, Tomes I and II, (Paris, Doin), p. 479.

CLIAS, P. H. (1843), Callisthénie ou somascétique naturelle appropriée à l'éducation physique des jeunes filles (Paris, Charles Deis).

COLL., (1888-1889) La vie au grand air (Paris, La Vie au Grand Air).

COLL., (1908) Manuel d'exercices physiques et de jeux scolaires, (Paris, Hachette).

COLL., (1921) Le Miroir des sports, 22 Décembre (Paris, Le Miroir des Sports).

COLL., (1921, 1922, 1923) Le miroir des sports (Paris, Le miroir des sports).

COLL., (1924) Encyclopédie des sports. Tome II (Paris, Librairie de France).

COLL., (1925) Règlement général d'éducation physique méthode française (Paris, C. Lavauzelles et cie),

COLL., (1934 à 1937) Revue du Cercle Bonnecompagnie (St Gilles Bruxelles, Cercle Bonnecompagnie).

COLL., (1978) Revue Quel corps ?, 10/11, (Paris, Quel Corps ?).

COLL., (1979) Revue Quel corps ?, 12/13, (Paris, Quel Corps ?).

COUVREUR, E. (1890) Les exercices du corps. Le développement de la force et de l'adresse (Paris, Alcan).

DALLY, E. (1886) Gymnastique, in DECHAMBRE \& L. LEREBOULLET (Eds.) Dictionnaire encyclopédique des sciences médicales (Paris 1886), pp. 792-869.

DAVISSE A. \& LOUVEAU C. (2000, 1st pub. 1998) Sports, école, société : la différence des sexes : féminin, masculin et activités sportives (Paris : L'Harmattan)

DAVISSE, A. \& LOUVEAU, C. (1991) Sports, école, société: la part des femmes (Paris, Actio).

DE COUBERTIN, P. de (1905) La gymnastique utilitaire (Paris, Alcan).

DEFRANCE, J. (1987) L'Excellence corporelle (Rennes, AFRAPS et PUR).

DEMENY, G. (1902), Les bases scientifiques de l'Education physique(Paris, Alcan).

DEMENY, G. (1924, 1rst ed. 1903) Mécanisme et éducation des mouvements (Paris, Alcan).

FERRY, J. (1870) Lecture in the Salle Molière, April 1870, cited by PARIAS L.-H. (1981) Histoire générale de l'enseignement et l'éducation en France. Tome III. De la révolution à l'école républicaine (Paris, Nouvelle Librairie de France), p. 143.

FONSSAGRIVES, J.-B. (1869) L'Education physique des jeunes filles (Carcassonne, V. Masson).

FOUCAULT, M. (1961) Histoire de la folie à l'Age classique, (Paris, Gallimard).

FOUCAULT, M. (1966) Les Mots et les choses, (Paris, Gallimard).

FOUCAULT, M. (1969) L'Archéologie du savoir, (Paris, Gallimard).

FOUCAULT, M. (1975) Surveiller et punir (Paris, Gallimard).

FOUCAULT, M. (1983) Usage des plaisirs et techniques de soi, Revue Le débat, 27, (Paris nov. 1983), pp. 46-72.

FOUCAULT, M. (1993) Sur Kant, in: COLL. Les inédits du magazine littéraire, 309, (Paris Avril 1993), pp. 62-73.

FRECCERO, R. \& GLEYSE, J. (2002) La Fabrica dei corpi, (Torino, Levrotto \& Bella).

GLEYSE, J. (1995) Archéologie de l'Education physique au XXe siècle en France, (Paris, PUF).

GLEYSE, J. (1997) L'Instrumentalisation du corps (Paris, Montréal, L'Harmattan).

HEBERT, G. (1911) Le Code de la force, (Paris, Vrin). 
HEBERT, G. (1919) Muscle et beauté plastique féminine (Paris, Vrin).

HEBERT, G. (1936) L'Education physique virile et morale par la méthode naturelle (Paris, Vrin).

HEBRARD A. (1987) L'Education physique réflexions et perspectives, (Paris, EPS).

HECKEL, F. (1913) Culture physique et cure d'exercice, (Paris, Masson et Cie).

HENIG, H. (1911) La pratique des exercices physiques (Paris, Baillères et fils).

JEUDON, R. (1930) Les gymnastiques féminines, in: LABBE M. (1930), Traité d'éducation physique,

Tomes I and II, (Paris, Doin), p. 539-578.

KUMLIEN, L.G. (1905) La gymnastique pour tous (Paris, Librairie des Annales).

LABBE, M. (1930) Traité d'éducation physique, Tomes I and II, (Paris, Doin).

LAGRANGE, F. (1888) Physiologie des exercices du corps (Paris, Alcan).

LELIEVRE, C. \& F. (1991) Histoire de la scolarisation des filles (Paris, Nathan).

MONTREYNAUD, F. (1989) Le XXe siècle des femmes (Paris, Larousse).

MORIN, E. (1988) La connaissance de la connaissance (Paris, Seuil).

MOSCONI N. (1987) La mixité dans l'enseignement secondaire un faux-semblant, (Paris, PUF).

MOSCONI, N. (2000, 1rst pub. 1994) Femmes et savoir : la société, l'école et la division sexuelle des savoirs, (Paris, L'Harmattan).

NOBECOUR T P. \& SCHREIBER, G. (1921) Hygiène sociale de l'enfance (Paris, Masson et Cie).

PARIAS, L.-H. (1981) Histoire générale de l'enseignement et l'éducation en France. Tome III. De la révolution à l'école républicaine (Paris, Nouvelle Librairie de France).

PECAUT, E. (1882) Cours d'hygiène (Paris, Hachette).

POCIELLO, C. (1981) Sport et societé, (Paris, Vigot).

ROSTAN, \& PRAVAZ, (s. p., 1836) Gymnastique, in: BECHET (Ed.) Dictionnaire de Médecine ou répertoire général des sciences médicales, Tome XIV (Paris, Bechet), pp. 450-476.

TARTAKOWSKY, D. \& WILLARD, C. (1981) Histoire de la France contemporaine, Tome IV (Paris, Editions Sociales).

TISSIE, P. (1901) Education physique au point de vue... (Paris, Larousse).

TISSIE, P. (1904) Précis de gymnastique rationnelle de plain-pied et à mains libres (Bordeaux, Bière).

TISSIE, P. (1919) L'Education physique et la race. Travail, santé, longévité (Paris, Flammarion).

VIGARELLO, G. (1993) Le Sain et le malsain (Paris, Seuil).

VINCELLO, M. (1933) Femme cultive ton corps (Paris, Chiron).

\footnotetext{
${ }^{1}$ This law provided for girls to have access to primary and secondary school, but not (under the pressure exercised by the conservative members, among them Jules Simon) to be taught Latin, Greek or philosophy, which were considered the reserve of mature men. Only an introduction to science was taught. However, gymnastics formed part of the scholastic programme. This law thus has great significance in this matter. The law was complemented by that of $28^{\text {th }}$ March 1882 (Ferry).

2 The Falloux law allowed young girls in primary to be taught the same subjects as the boys with the addition of needlework. In addition the law stated in article 51 that: every commune (parish) of 800 souls and more shall, if it has the resources available, to have at least one girl's school".
} 


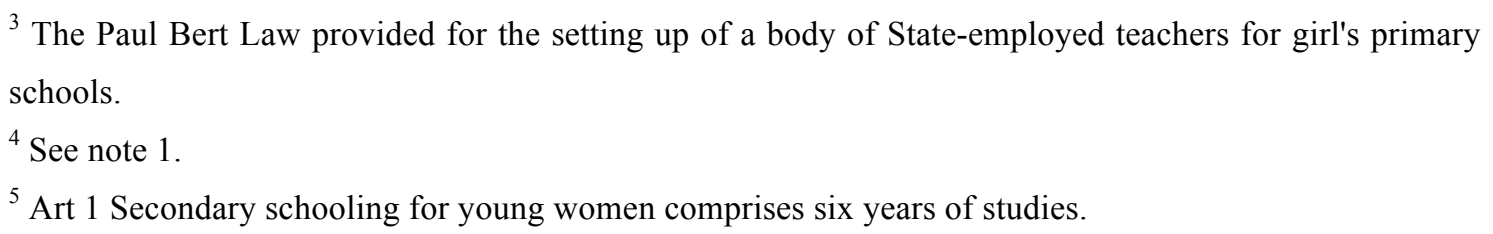

Art 2 The diploma at the end of studies [...] shall be accorded after the final year of study classes, following an examination whose subject matter shall be set by ministerial decree.

Art 3 Alongside the instruction tested by the diploma, optional classes that are tested by the baccalaureate are instituted in high school and junior school.

Art 4 Programs of instruction for boys are fully inclusive of the optional instruction mentioned in article 3 , which apply to all the jointly instructed subjects that are tested by the diploma.

${ }^{6}$ It is noteworthy too, that if only $50 \%$ of the female population had non-domestic employment up to the 1970 s, the number of women workers in the secondary or service industries was much greater than the number of men. On this subject, see Claude \& Françoise Lelièvre, Histoire de la scolarisation des filles, (Paris 1991), p. 138.

${ }^{7}$ Jules Ferry lecture in the Salle Molière, April 1870, cited by Louis Henri Parias, Histoire générale de l'enseignement et l'éducation en France. Tome III. De la révolution à l'école républicaine, (Paris, 1981), p. 143.

8 Jean-Jacques Rousseau, Philosopher of Light, in "Emile où de l'éducation", explains the need for a balance between the body and the spirit and hails physical education as a vector for intellectual learning.

${ }^{9}$ Pierre De Coubertin, in any event, was never much in favour of female practice as in 1905 he wrote: "It is obvious that by its very purpose utilitarian gymnastics is unsuitable for young women." Pierre De Coubertin, La gymnastique utilitaire, (Paris 1905), p. X.

${ }^{10}$ It worth adding a transcript here of the whole the paper quoted in illustration: "... Just one enthusiasm consumed Emily: to achieve through the effort of her own muscles, results that the muscular effort of no other woman could achieve, nor the majority of men either. All her energy was committed to this goal. Her life was divided into two parts: in one, she fought for mastery of the racket and the pedal; in the other she trained for these fights. Her conversation was wondrously void of spiritual subjects. There was no point in talking to her of a book or a recent artistic event, no point in raising the subject of a political crisis or a social movement. All she reads is Auteuil-Longcham, Le Vélo, and the pages of newspapers that provide a daily summary of sport from all over the world. However, she will talk effusively of them with a frightening facility of expression; she will treat you to all the specialist jargon, all the usual abbreviations that are used by the professionals and, what is even more admirable is that she is very sincerely convinced that these are the most noble concerns and she observes, from the summit of sincere 
disdain, the inferior mortals for whom the sum of ambition is not to manoeuvre, following arbitrary and precise laws, the muscular apparatus of their arms or their shanks." (Marcel Prévost, "Letter to Françoise", in Charles Ab Der Halden, Leçons de morales. Ecoles primaires supérieures, p. 19.). It can be seen that the same ideology that attributed to sports enthusiasts an intelligence level in inverse proportion to their muscles is applied with ease to women.

${ }^{11}$ For the three years examined, only 29 articles were found on female sport. These articles appear in the following editions:

$1 / 06 / 21,1 / 09 / 21,29 / 09 / 21,3 / 11 / 21,10 / 11 / 21,1 / 12 / 21,12 / 01 / 22,19 / 01 / 22,23 / 02 / 22,9 / 03 / 22,4 / 05 / 22$, $15 / 06 / 22,22 / 06 / 22,3 / 08 / 22,17 / 08 / 22,24 / 08 / 22,7 / 09 / 22,24 / 11 / 21,22 / 12 / 22,22 / 03 / 23$ (there are sometimes up to three articles in the same issue). Most are relatively short: 5 deal with tennis, 5 with swimming (both bathing and competition swimming), 5 are on athletics, 3 on football, 2 on golf, 1 on polo, 1 on water base-ball, 1 on basketball, 1 on hockey, 1 on female sport in Czechoslovakia, 1 on skating, 1 on the Monte Carlo Olympic Games, 1 by Irene Popard, star of the week, 1 on physical culture for women. Analysing the articles on men shows that the writings are predominantly centred on football, boxing, cycling and the mechanised sports. Very few are on the activities that were favoured by women. Those articles that deal with innovative sports (water baseball etc) are always tied to female sports. It is also the case overall for "sports of strategy" and "informational" sports. Be that as it may, the small number of articles devoted to female sport, as well as their specifically innovative nature, is evidence of the fact that women have a special place as much in the sports institution and the world of bodily practice as in the social world. This situation was to change radically at the end of the twentieth century.

${ }^{12}$ Years 1898 and 1899 were analysed from issues 1 to 40

${ }^{13}$ Georges Hébert, Le Code de la force, (Paris 1911), p. 106.

${ }^{14}$ Georges Vigarello, Le Sain et le malsain, (Paris 1993).

${ }^{15}$ This point of view has already been elucidated by Gleyse, 1997, Liotard, 1997 and Kirk, 2002. 